This article belongs to the Special Issue Public sector Innovation Conceptual and Methodological Implications

Guest Editors: Ann Karin Tennås Holmen (UiS), Maria Røhnebæk (INN)

\title{
The relationship between research and innovation in the public sector - an analysis of five cases from labour and welfare services
}

\author{
Magnus Gulbrandsen* \\ TIK Centre for Technology, Innovation and Culture \\ University of Oslo \\ Email: magnus.gulbrandsen@tik.uio.no \\ *corresponding author

\section{Gry Cecilie Lunder Høiland} \\ TIK Centre for Technology, Innovation and Culture \\ University of Oslo, Norway / \\ Faculty of Economics and Management \\ NTNU, Norway \\ Email: gry.c.l.hoiland@ntnu.no
}

\begin{abstract}
Many public agencies promote renewal in the public sector through projects that require a productive combination of research and innovation activities.

However, the role of research in innovation processes is a neglected theme in the public sector innovation literature. We address this gap through an analysis of five cases from the Norwegian Labour and Welfare Administration. We find few examples of innovations based directly on research, but several examples of research on innovations and on more complex co-evolutionary processes of the two activities. Research seems to be particularly important for the diffusion and scaling up of innovations. We find that research has an impact on innovation in later phases of the innovation process through the
\end{abstract}


formalisation of practice-based and unsystematic knowledge, codification of experiences, and legitimation to ensure political support and funding. This new conceptualisation contributes to the public sector innovation literature and may help improve policies that set up a rather limited role for research.

Keywords: Public sector innovation, the chain-linked model, relationship between research and innovation, research policy, innovation policy.

\section{Introduction}

Research and innovation-separately and together-are major instruments for addressing societal challenges in Western welfare states. Linkages between research actors and organisations in industry and the public sector have emerged as a central topic in the academic literature. Even if research is expected to make a societal impact, including an impact on innovation processes, this literature has repeatedly warned against simple linear models. For example, many scholars, including Mowery et al., warn against the notion that innovation is mostly based on ideas emerging from research (2004). The underlying argument is that research, the systematic creation of new knowledge, and innovation, the practical implementation of new ideas to generate some form of value, are fundamentally different activities, even if they benefit one another at times or have some overlap.

In this paper, we ask how the relationship between research and innovation can be characterised in the context of public sector innovation. The relationship has been weakly conceptualised in the public sector innovation literature, and we focus on the link between the way research influences innovation processes and the role of research in different phases of innovation. We study areas in which governments emphasize research-based knowledge and innovation, basing our empirical analysis on five innovation processes in the Norwegian Labour and Welfare Administration (NAV).

In the next section, we discuss some central writings on the relationship between research and innovation. The subsequent section contains notes on our empirical data and method, followed by a presentation of the five cases. Then we proceed to analyse three types of relationships in the material: research-based innovations, research carried out on innovations, and more complex ways in which innovating public organisations become engaged in 
$R \& D$ in various innovation phases. In the final section, we conclude that the role of research as a clear source of ideas for innovation is probably exaggerated, while its impact on other aspects of innovation processes might be undervalued. These findings have important implications for science and innovation policies targeting the public sector.

\section{Theoretical perspectives}

Innovation represents the introduction of novelty to a practical setting, such as launching a new product or service or implementing a new organisational form. Innovation is a much broader and more complex phenomenon than "invention" or "research breakthroughs" (Fagerberg, 2005). Innovation processes are often lengthy, unpredictable, and hard to manage (Van de Ven et al., 1999; Pavitt, 2005; Garud et al., 2013).

Although empirical studies find many similarities between firms and public organisations in how innovation plays out through different stages (van de Ven et al., 1999), public sector innovation is mostly theorised as distinct from private sector innovation (Hartley, 2005; Høiland, 2018). Both are motivated by value creation, conceptualised as economic values and competition for survival in the private sector, and democratic governance, shared cultural values, and concern for citizens in the public sector (Fuglsang \& Rønning, 2014; Bason, 2010). As a result of innovation's high visibility on political agendas (Mazzucato, 2018) and the request for evidence-based policymaking (Greenhalgh \& Russell, 2009; Howlett, 2009), governments increasingly view innovation and research as essential tools for developing public services and making them research-based (e.g., Ministry of Health and Care Services, 2014).

Perspectives on the role of research and development (R\&D) in innovation have changed over time. Early work most often framed innovation as advanced technological change involving $R \& D$, while later perspectives tied $R \& D$ to an organisational capacity to use external knowledge and to evaluate and monitor external developments (Cohen \& Levinthal, 1989). Furthermore, collaborative and systemic perspectives have argued that firms' innovation activities in many industries have co-evolved with external public research, but due more to the research-based education activities in universities than inventions originating from academic research (Rosenberg \& Nelson, 1994). 
Historical investigations have shown the importance of applied and missionoriented research organisations for innovation (e.g., Gulbrandsen \& Nerdrum, 2009, for Norway).

However, the question of how $R \& D$ relates to innovation is barely addressed in the public sector innovation literature (DeVries et al., 2016), despite policy assumptions that the sector's collaboration with research organisations will increase the likelihood of innovation (cf. Sørensen \& Torfing, 2011; Torfing et al., 2016). The literature has looked into the nature of public sector innovation with themes such as typologies, antecedents, barriers and facilitators (e.g., DeVries et al., 2016; Hartley, 2005; Fuglsang \& Rønning, 2014). Implementation studies have sometimes investigated how research- or evidence-based knowledge is utilised in sectors such as health, welfare, and education (e.g., Heaton, et. al., 2016; Parkes, et. al, 2014; Harrison \& Graham, 2012; Rycroft-Malone et al., 2011). Nevertheless, this tradition either does not deal specifically with how research is related to innovation activities and processes, or implicitly assumes that research is the source of the idea for the innovation.

Process perspectives offer a more detailed view of how the relationship between R\&D and innovation plays out over time. Theoretical and empirical investigations highlight that innovation processes involve a multitude of actors, including R\&D providers, and that partnerships may shift over time (e.g., van de Ven et al., 1999). Furthermore, even if innovation processes rarely progress linearly and neatly, certain phases can be identified, such as idea/initiation, development, and implementation/diffusion (Garud et al., 2013). Although individual action and organisational decisions can be important, innovation processes are often influenced by complex combinations of wider institutional factors, such as market forces and the forces of scientific and technological developments (Kline \& Rosenberg, 1986; Garud et al., 2013). A process perspective implies a shift from seeing innovations as specific outcomes to a focus on the change or transformation processes that are involved in innovation (Garud et al., 2013).

Kline \& Rosenberg (1986), in their widely used "chain-linked model" of innovation, argue that innovation and research are largely independent of one another. Innovation starts with a need, a problem, a potential market, or something similar and an "analytic design" develops in response. What follows 
is a set of stages in which the design or idea is developed, tested, redesigned, and implemented, but the stages are not neatly ordered, and a return to "earlier" stages is very common. Research, on the other hand, starts with a question for which there is no clear existing answer. In most cases, this involves a qualitatively different "need" than that of innovation, as research is rooted in knowledge gaps and the potential for original contributions to theoretical, methodological, empirical, and applied challenges. Research output can take the form of a publication, a lecture, or something else, which then becomes available library material, databases, teaching initiatives, deliverables to project partners, and more.

We have used the chain-linked model to set up three idealised relationships between research and innovation with the public sector in mind. The first we have called research-to-innovation, which denotes instances where research produces a result or an idea that forms the starting point of an innovation process. Kline and Rosenberg (1986) argue that this is an important but also rare phenomenon, as most innovation processes have other origins and driving forces.

The second relationship is termed innovation-to-research or research-oninnovation. Innovation can create direct opportunities for research, as in the case of new scientific instruments and data. More frequently, various innovation-related practices are a key object of study in many research fields where the aim is to understand, explore, and explain important societal phenomena. For example, scientists may study service provision in healthcare, welfare, or education to gain insights into central social processes.

Finally, we have named the third idealised relationship research-in-innovation. When an innovation process halts because there is a lack of knowledge, the participants will (most often) search through available knowledge stocks (texts, asking people, etc.). Only if this does not provide an adequate answer, research is needed. This can happen at different stages of an innovation process (e.g., the idea itself requires more knowledge), or in development and implementation. In this relationship, research activities are to some extent initiated by innovation needs, but not necessarily directly by market forces or purely practical considerations. These three types can represent an analytical scheme for looking more closely at the relationship between research and 
innovation in the public sector, and we will return to them after presenting the data material and the five cases.

To conclude, innovation studies have enjoyed policy influence based on arguments and findings that innovation and technological change are related to economic growth and societal change. However, the field's more complex message - that research is primarily a source of indirect learning and competence building rather than a source of inventions and ideas that can be commercialised and implemented-is often lost when translated into policies (Berman, 2012). Consequently, warnings have appeared in the innovation literature against policies and perspectives that focus on research and commercialisation as primary drivers of innovation. Although innovation activities can, at times, be traced back to earlier research, ideas of a causal, or stage-wise relationship, or a clear division of labour, have been repeatedly denounced (cf. Balconi et al., 2010). There is concern that policies may place unrealistic or detrimental demands on science or emphasise only a few, highrisk forms of innovation (Rosenberg \& Nelson, 1994). In the context of governments emphasising innovation and evidence-based policies in the public sector, this concern remains relevant. Public sector innovation processes are often seen as more complex and heterogeneous than private sector innovations (Bugge \& Bloch, 2016). As such, the concern of a "too linear" understanding of research-innovation relations may be even more pressing for public sector innovation, which has diverse objectives and concerns public values such as democracy, safety, trust, and meeting societal challenges (Bason, 2010).

Three analytical lenses for our empirical analysis emerge from this brief literature review. First, there are several theoretically founded relationships between research and innovation in the literature, and we have set up three idealised ones. Second, innovation processes most often have distinct phases, and we will explore the relationship between research and innovation in these. Third, a process perspective implies an interest in how research activities have an impact on the innovation process itself rather than on specific innovation outcomes. 


\section{Research setting and methods}

The Directorate of Labour and Welfare (NAV) is responsible for providing employment and welfare services and administers one-third of Norway's national budget. There are high expectations that policy decisions about welfare and employment should be based on documented effects and the best available science. In NAV, a substantial proportion of the R\&D budget is allocated to work inclusion services, with the specific assumption that these investments will lead to better employment services, more efficient use of public resources, and improved work inclusion outcomes. In this paper, we draw upon an ongoing study of innovations and the impact of research in NAV.

Using an explorative approach (Eisenhardt, 1989), we interviewed a large number of civil servants in leadership and coordinator positions at NAV's headquarters and some of their research partners. Interviewees were not selected because they represented the five cases analysed in this article, but because they were involved in the use of research and coordination of innovation more generally. The interviews employed a guide asking in-depth but open-ended questions, probing for examples about practices and processes of knowledge acquisition, research collaborations, and policy development in NAV. The interviews were recorded and transcribed and lasted between 60 and 90 minutes. Both authors read the transcripts several times, discussed them, and coded themes inductively in Nvivo.

For this paper, we read through the interviews and identified five service innovation cases that all illustrated some aspects of the relationship between research and innovation in NAV. We selected 15 interviews that all referred to at least one of these five cases, and we reviewed a large number of documents through access to the NAV internal network. We also used secondary sources such as final and interim research reports. The internal documents included calls for research and descriptions of research results and were either directly related to the cases or helpful for understanding how NAV conceptualises research-innovation linkages. None of the interviewees had been directly responsible for the five service innovations, but they had in various ways been involved in funding decisions, other support, coordination of $R \& D$, or similar tasks. Table 1 gives an overview of the data sources. 
For modifying a theoretical model rather than testing certain propositions, we used a dialogical approach to study the interplay between empirical data and theory (Rule \& John, 2015). Having inductively and thematically coded our interviews prior to this paper, we created a new set of codes categorizing directions and forms of interactions as well as examples of innovations and the use of research. We looked for mentions of research when participants talked about innovations and vice versa.

Table 1: Data sources.

\begin{tabular}{|l|l|}
\hline Data sources & Description \\
\hline 5 interviews & Leaders \& coordinators @Directorate R\&D department \\
\hline 5 interviews & $\begin{array}{l}\text { Leaders \& coordinators @Directorate service } \\
\text { development department }\end{array}$ \\
\hline 5 interviews & Researchers @Research organisations \\
\hline 69 documents & Internal documents NAV \\
\hline 26 documents & Research reports \\
\hline
\end{tabular}

We found many indications that the role of research varied between different innovation processes. Following the dialogic approach (Rule \& John, 2015), we started comparing our codes to our three stylised relations inspired particularly by Kline and Rosenberg (1986), classifying them accordingly in our last cycle of coding. Reflecting upon our data's fit and lack of fit, we sought to develop a refined understanding of the relationship between innovation and research in public sector settings.

The findings are based on an analysis of a handful of innovation processes within NAV, an organisation that emphasises evidence-based decisions. Caution should therefore be taken in generalisations, but our modified understanding of the research-innovation relationship may be relevant for other evidence-focused parts of the public sector, such as health and education. Even if welfare services may be less tailored to randomized controlled trials as in medicine and less influenced by powerful professional values and positions, these aspects were nevertheless highlighted by many interviewees. All the same, further studies are needed to develop a more comprehensive understanding of the relationship between innovation and research in the public sector. 


\section{The cases and research-innovation relationships}

This section contains a brief description of each case and a first analysis of the main patterns of research-innovation relationships in each.

\section{Case 1: Supported employment in NAV}

NAV is responsible for providing employment services to people with the need to find or maintain a job. Supported employment (SE) is an internationally recognized work inclusion method for our purpose, an innovation (or set of innovations) aiming to support people in gaining employment in mainstream jobs instead of vocational rehabilitation through sheltered workshops. It prescribes several principles, including the enlistment of "job specialists" who closely follow up on the service user.

Early SE principles in Norway can be found in the 1990s in an earlier labour agency. In 2012, a public committee consisting of researchers, policymakers and other experts nominated SE as the preferred model of work inclusion, calling for more R\&D collaborations for developing better SE services and suggesting that NAV itself could take over more of the work inclusion services (NOU, 2012). As such, SE in NAV is a case in which a top-down initiative drives the innovation process, but with research influence on early priorities and framings. Its further fate can be traced through several innovation phases and research projects, from the need to develop the method in the context of NAV to the testing, redesign and implementation taking place since 2012. Working to develop and provide SE services through internal agency resources, NAV has leaned on researchers in major parts of the process. Researchers were commissioned to collaborate in developing and implementing SE methods in selected NAV offices (Spelkavik et al., 2016a). A number of research projects were procured to evaluate and test the method more broadly (Spelkavik et al., 2016b; Schönfelder, 2020; Bakkeli, 2020). As a part of designing manuals for implementing and securing the quality of SE services in NAV, for example, researchers were involved in evaluating SE manuals and in providing knowledge-based input for simplifications and improvements to support SE quality, effectiveness, and cost efficiency.

\section{Case 2: Individual placement and support}

Individual placement and support (IPS) is a related case of a work inclusion innovation in NAV. Compared to SE, IPS represents a different strategy with 
another implementation agenda and different actors. It is a specific evidencebased supported employment approach based on extensive research through randomised controlled trials (RCTs), and the approach has a manual and fidelity scale that should be followed strictly (Drake et al., 1999). As such, it is an example of an innovation where the initial idea had strong links to international research efforts.

When the 2012 public expert committee approved supported employment methodology in employment services (NOU 2012), IPS surfaced as a welldocumented evidence-based approach in the international research community. As part of a national initiative to implement IPS services on a large scale, the first RCT of evidence-based IPS in Norway was done as commissioned research starting in 2012 (Sveinsdottir et al., 2019). In close collaboration with NAV and health institutions, researchers experimented with IPS as a new work inclusion approach. Six pilot offices utilised the IPS models as part of the RCT. Results in 2016 revealed the IPS pilots to be significantly more effective than traditional methods (Reme et al., 2016). IPS thus became a benchmark for evidence-based policy in NAV, which has further developed the method through trials for other user groups and implemented it nationwide in continuous collaborations with IPS researchers.

\section{Case 3: Motivational interviewing}

Because many NAV frontline counsellors are not formally educated within social work, the Ministry of Labour assigned the development, implementation, and evaluation of a programme for better client follow-up to the directorate in 2009. The programme was developed based on international research on counselling techniques, and NAV commissioned researchers to evaluate the implementation process and the effect of a pilot on counselling practices. The researchers found that the conversation method called Motivational Interviewing (MI) was warmly approved by frontline workers (MalmbergHeimonen, 2014). The method itself was initially developed by clinical psychologists and published scientifically from the late 1980s, but the first NAV variant had only weak and indirect links to these efforts. Counsellors in NAV offices nationwide received training, and the counselling method was widely implemented. Seeking further evidence of the effects of MI on employment outcomes, the directorate's R\&D department ordered a systematic review by the National Institute of Public Health (2017). The review found no evidence that the method improved employment outcomes. More 
recently, two randomised trials have been set up in collaboration with research institutes and partly funded by the Research Council.

\section{Case 4: HOLF model for follow-up of low-income families}

Acting on a call from the Ministry of Labour, NAV commissioned a systematic review in 2014 from a research institute that showed a lack of research on effective measures against child poverty in Norway. The directorate decided to initiate an R\&D project to develop and test a new model for relevant NAV services. Using the findings of the systematic review, as well as considerations of frontline experiences, a pilot called HOLF (holistic follow-up of low-income families) was developed in a collaboration between the directorate and frontline offices and not based directly on research. However, as a part of this innovation process, the $R \& D$ department procured research to evaluate and advise the process of development, to test its effect using RCTs, and to evaluate the process of implementation. The purpose of the research collaboration was to determine whether the intervention worked and should be implemented nationwide. The evaluation indicated that frontline employees perceived more systematic follow-up of service recipients (MalmbergHeimonen 2019), but because the RCT results did not show any significant effects, HOLF was put on hold.

\section{Case 5: The Hedmark model for reduced sick leave}

Aiming to solve the problem of their region's holding the highest sick leave rate in Norway, the manager of a regional NAV office in 2013 initiated the development and implementation of a new model related to NAV's routines for handling sick leave benefits. An effect evaluation found that after the introduction of the model, the region had the largest reduction in sick leave in the country. NAV decided to launch a trial to introduce the model in three new regions. The latter experiment was delegated to external researchers for process evaluations, although some routines of the model were diffused before the launch of the trial and evaluations (Proba Samfunnsanalyse, 2016). The process evaluation was positive and influenced the diffusion of the model nationally. In parallel to the external research evaluation, NAV's own R\&D department conducted an effect evaluation (NAV-rapport nr 3-2017), which also concluded that the model should be implemented nationwide. 


\section{Driving forces of innovation in NAV}

We found four categories of driving forces in the cases. The first is when innovation processes are initiated by political agendas and handed down as administrative orders to the Directorate of Labour and Welfare (NAV) from the Ministry of Labour and Social Affairs. Processes initiated in this way often appear as a mix of political priorities surrounding societal problems and existing knowledge, but may in some cases originate from established research results and media publicity. This top-down process is an important part of the two supported employment cases: motivational interviewing and low-income family follow-up methods.

The second driver of innovation, exemplified in the Hedmark model, is a need defined at the operational level of the organisation. Here, the process starts with an everyday or local problem experienced by middle-line managers or frontline employees, and solutions are enacted or proposed by the same actors.

A third driver for innovation is related to the first two: innovation as prescribed by the Ministry or based on detected problem areas in the welfare system, which end up in NAV as directives to be followed up on or as initiatives that might be scaled up or diffused. Although these processes use existing knowledge, competence, and collaborations among civil servants in the Ministry and the directorate, research is often needed. For this research to be sufficiently relevant and useful, a knowledge infrastructure needs to be in place. The establishment of a separate R\&D department in NAV was, according to the interviewees, driven by an observed need for more relevant and higher quality research, as well as a more systematic procurement and use of it. The size of NAV and the opportunity to follow ongoing experiments with a possible control group set-up make it interesting for researchers to become engaged in innovation-related work as well. All our cases except the Hedmark model contain some elements of such Ministry-initiated processes targeting specific challenges.

Only IPS can clearly be defined as an innovation process that (to some degree) was initiated by research. The approach, with its fidelity scale, emerged from international results of randomised controlled trials, although later R\&D responded to NAV calls for studying and monitoring the various experiments with IPS. In the other cases, a new kind of relationship between 
NAV and researchers seems to have emerged, in which research over time moves from such a responsive mode to more of a source of new ideas.

Examples are the HOLF and Ml cases, as well as the more general supported employment work apart from IPS.

Table 2: Innovation cases

\begin{tabular}{|c|c|c|c|}
\hline Case & Description & $\begin{array}{l}\text { Driving force of } \\
\text { innovation process }\end{array}$ & $\begin{array}{c}\text { Role of research in } \\
\text { the innovation } \\
\text { process }\end{array}$ \\
\hline $\begin{array}{l}\text { 1: Supported } \\
\text { employment } \\
\text { (SE) }\end{array}$ & $\begin{array}{l}\text { A work inclusion method } \\
\text { with the goal to support } \\
\text { people in achieving } \\
\text { steady, meaningful } \\
\text { employment in } \\
\text { mainstream jobs, not } \\
\text { vocational rehabilitation } \\
\text { through sheltered } \\
\text { workshops }\end{array}$ & $\begin{array}{l}\text { Political agenda } \\
\text { (reduce } \\
\text { unemployment) and } \\
\text { orders from the } \\
\text { Ministry and detected } \\
\text { problem areas in the } \\
\text { organisation }\end{array}$ & $\begin{array}{l}\text { Idea for the effort partly } \\
\text { inspired by research, } \\
\text { but main role to } \\
\text { develop and implement } \\
\text { the approach }\end{array}$ \\
\hline $\begin{array}{l}\text { 2: Individual } \\
\text { placement } \\
\text { and support } \\
\text { (IPS) }\end{array}$ & $\begin{array}{l}\text { A supported employment- } \\
\text { derived method and an } \\
\text { evidence-based approach } \\
\text { to work inclusion. IPS has } \\
\text { been extensively } \\
\text { researched and proven to } \\
\text { be effective internationally } \\
\text { compared to standard } \\
\text { employment services }\end{array}$ & $\begin{array}{l}\text { International research } \\
\text { results, } \\
\text { political agenda } \\
\text { (reduce } \\
\text { unemployment) and } \\
\text { orders from the } \\
\text { Ministry and detected } \\
\text { problem areas in the } \\
\text { organisation }\end{array}$ & $\begin{array}{l}\text { Idea for the service } \\
\text { strongly inspired by } \\
\text { research, early stage } \\
\text { test design } \\
\text { (randomised controlled } \\
\text { trial) and research } \\
\text { follow-up through } \\
\text { implementation }\end{array}$ \\
\hline $\begin{array}{l}\text { 3: } \\
\text { Motivational } \\
\text { interviewing } \\
\text { (MI) }\end{array}$ & $\begin{array}{l}\text { A communication method } \\
\text { to improve counselling } \\
\text { sessions with clients }\end{array}$ & $\begin{array}{l}\text { A combination of } \\
\text { orders from the } \\
\text { Ministry (perceived } \\
\text { competence gap } \\
\text { among frontline } \\
\text { employees) and } \\
\text { detected problem } \\
\text { areas in the } \\
\text { organisation }\end{array}$ & $\begin{array}{l}\text { Idea came from a } \\
\text { review of relevant } \\
\text { research; innovation } \\
\text { developed and } \\
\text { implemented by NAV; } \\
\text { research used for } \\
\text { measuring effects } \\
(\mathrm{RCT}) ; \text { further } \\
\text { implementation } \\
\text { depending on research } \\
\text { results }\end{array}$ \\
\hline 4: HOLF & $\begin{array}{l}\text { A method for "holistic } \\
\text { follow-up" of low-income } \\
\text { families }\end{array}$ & $\begin{array}{l}\text { Political agenda } \\
\text { (reducing child } \\
\text { poverty), ministerial } \\
\text { initiative and initial } \\
\text { internally funded R\&D } \\
\text { project }\end{array}$ & $\begin{array}{l}\text { Research primarily } \\
\text { used to evaluate and } \\
\text { advise the } \\
\text { development and } \\
\text { implementation } \\
\text { process; RCT to test } \\
\text { effects leading to } \\
\text { decision to discontinue }\end{array}$ \\
\hline $\begin{array}{l}\text { The Hedmark } \\
\text { model }\end{array}$ & $\begin{array}{l}\text { A model to decrease sick } \\
\text { leave in the Norwegian } \\
\text { labour market }\end{array}$ & $\begin{array}{l}\text { Mid-managerial driven } \\
\text { based on detected } \\
\text { problem areas in the } \\
\text { organisation }\end{array}$ & $\begin{array}{l}\text { Innovation developed } \\
\text { by NAV and effect } \\
\text { tested by NAV, then } \\
\text { central routines } \\
\text { introduced nationally - } \\
\text { research involved to } \\
\text { influence further } \\
\text { development before } \\
\text { national } \\
\text { implementation }\end{array}$ \\
\hline
\end{tabular}


Table 2 shows an overview of our innovation cases, a summary of their main driving forces, and an indication of the overall role of research in the innovation process. In sum, we find that political decisions, ministry initiatives, and managerial problem-solving appear as important drivers of innovation. Still, we find that research activities were a part of the innovation processes in all the cases, even though it was only in the IPS case that they provided the initial idea or framing.

\section{Research in welfare innovation processes}

The previous section showed that our data support perspectives highlighting the indirect and process aspects of the research-innovation relationship. Here, we analyse these relationships in detail, using the three idealised types that we developed in our theory section based on innovation process perspectives inspired by Kline and Rosenberg (1986), as well as the phases of Garud et al. (2013).

\section{Research-to-innovation}

We found that in four of the cases, research was part of the early phase (emergence of the idea) of the innovation process. As mentioned, the innovation process that is easiest to categorise as research-to-innovation is IPS, which was initiated by two major research projects involving social scientists in collaboration with NAV. The source was collaborative research but also earlier independent academic research. The Ministry of Social Affairs funded the collaborative projects, which involved a complex randomised controlled setup, then delegated them to NAV for day-to-day research partnerships and support. NAV interviewees clearly attributed the starting point of IPS to research results. The projects delivered strong support for this new approach to work inclusion, indicating that IPS (and possibly SE more generally) was the most effective work inclusion method available. This resulted in an emphasis on diffusing IPS, a multi-year task in collaboration with several research organisations that also catalysed the implementation of other SE innovations.

Even if this seems like a clear case of research leading to innovation, the interviews indicate a more complicated backstory. The general introduction of supported employment-related services in labour agencies from the $1990 \mathrm{~s}$ 
and onward was essential for the IPS process, suggesting that research-toinnovation may depend upon a certain maturity or absorptive capacity (cf. Cohen \& Levinthal, 1990).

The three cases of supported employment (SE), motivational interviews (MI), and holistic low-income family support (HOLF) to some extent used systematic reviews of relevant research in the early stages of the innovation processes. Both the IPS and SE cases were based on international research, though their diffusion to the NAV/Norway context differed. In the case of MI, international research literature inspired the idea. In HOLF, a systematic review showed a lack of knowledge in the field of child poverty, indicating a need to develop new services.

\section{Research-on-innovation}

We see some examples of research-on-innovation in our interviews, much of it funded by third parties like the Research Council of Norway. However, interviewees from NAV rarely mentioned such projects as important for their innovation cases, even if they knew about them and even if cases such as supported employment were the main topic of these projects. Most of their examples of useful research came from projects they had commissioned themselves through their R\&D department. This could indicate that within a large public organisation, many different relationships between research and innovation occur simultaneously, and that the challenges of learning and spreading information within the organisation can be considerable.

Furthermore, research-on-innovation projects often require close collaboration between (parts of) NAV and the research organisations. Some research programmes may require "user involvement", and issues of data access, availability and privacy can necessitate long-term and committed partnerships. This seemed to work fairly well, and the interviews indicate that some of the sub-regions in NAV had been particularly active in making their data, processes, and employees available for external research. Although the research aimed to understand work inside NAV and how its clients were doing, collaboration also ensured competence building and diffusion of research results and perspectives to NAV personnel. As such, a longer-term impact could be an influence on innovation within NAV. 
Tensions in these relationships were as expected: researchers worried about spending a lot of time "anchoring" a project with NAV when the success of support from a competitive programme was low, while NAV complained that sometimes they were contacted immediately before an application deadline. Over time, some of the research projects on NAV innovations funded by third parties have developed into the co-evolutionary type of partnership analysed in the next section.

\section{Research-in-innovation}

The third stylised relationship takes place when research is called upon at various stages of the innovation process in cases in which existing knowledge cannot solve apparent problems. Major parts of the innovation processesparticularly later stages - in our cases can be categorised here, and a main phenomenon is to call for research to evaluate effects or monitor implementation.

In the Hedmark model case, the innovation was initiated internally, and external research was called upon late in the process to evaluate the implementation of the innovation in other regions. Research entered earlier in the innovation processes in the two supported employment cases (SE and IPS). Here, research was commissioned to solve problems that arose during the development of the method to fit the national context. It was also used to test for effects and decide whether and how to implement the methods. The IPS research results legitimatised SE methods at top political levels and in the Ministry of Labour and the Ministry of Finance, securing further funding and a continued existence and national diffusion.

In addition, the HOLF case for helping low-income families had a strong emphasis on early collaboration between practice and research. The Directorate's R\&D department initiated a nationwide development and testing of HOLF in 2015. Because of a lack of evidence-based instruments for the target group, the project also aimed to test for effects to improve its knowledge for later scaling-up to NAV in its entirety. The testing was done in collaboration with researchers and through a sample of randomly selected NAV offices. One of the aims was to test, develop and form the basis for concrete recommendations and broader implementation in NAV and collaborative services. 
For the motivational interview case, research had an important role during the innovation process. The idea for the innovation was derived from international research after an internal initiative and piloted in collaboration with a research team before being implemented through extended training practices nationwide. Later evaluations by external researchers were again procured, primarily to evaluate its effect more systematically to legitimize its continuation.

The four cases of SE, IPS, HOLF, and MI display stronger relations over time between researchers and practitioners during formalised innovation processes in NAV. We found that the directorate connects researchers more and more to innovation processes in the operational parts of the organisation, and increasingly earlier. The idea is that by following the processes from the beginning, the knowledge will be more systematic and easier to diffuse than for the usual bottom-up innovations.

These examples of research within innovation processes demonstrate four important roles for the research activities. First, they provide an updated knowledge base of existing research and best practices in the field. Second, they provide more systematic knowledge about innovations initiated by frontline or local offices or by central management, which makes it easier to diffuse or scale up innovations. Third, they provide a collaborative "laboratory" for experimenting with and further developing innovations and related activities like training. Fourth, researchers evaluate the effects of service innovations to legitimise innovations' continued financing and diffusion. The material indicates that innovation processes are often initiated and implemented decoupled from research, but that research is increasingly perceived as important for further development, evaluation, testing, adjustments, and legitimacy.

\section{Phases and research-innovation relationships}

In sum, we see that the relationship between research and innovation varies between the phases of innovation processes. In the idea phase, research is primarily one source—out of several—of inspiration for ideas that may be developed into innovations. In the development phase, research provides useful knowledge in the form of systematic reviews, mapping of initial conditions and preparation for possible randomized controlled trials (RCTs), and assistance to develop generic or international concepts and solutions to a 
local context. This phase often sees close contact between researchers and the ones working with innovation. Finally, in the implementation phase, the main role of research is to provide insight into "what works," ranging from large-scale RCTs to smaller-scale monitoring and formative/follow-up studies. Here, several interviewees stressed how the independence of the research becomes an asset for the legitimacy of the innovations. We will return to this aspect in the concluding discussion.

The boundaries between the phases are not clear in several of the cases, mostly because development and implementation are often closely linked. There are also several types of implementation, from the first iteration in a smaller part of the welfare system to a scaling up of an innovation to the whole system. There may be a new phase of development and adaptation between these two forms of implementation. As such, our cases_even if they represent single innovations-are not single outcomes but "families" of solutions tied to larger challenges like unemployment and poverty. It is also possible that the increase in collaboration between innovation coordinators and external research organisations, including the emphasis on getting researchers engaged earlier in the process, contributes to blurred boundaries between phases as new external knowledge and ideas enter the process more often.

\section{Discussion and conclusion}

In this paper, we have explored the relationship between research and innovation in public sector innovation. Innovation scholars have repeatedly denounced the idea of a causal or instrumental relationship between research and innovation. Instead, they have proposed that the relationship is multifaceted and that the two processes are different and often independent from one another. However, little is known about the topic from the public sector innovation literature, and it is therefore relevant from both a policy and academic perspective to explore the relationship between research and innovation. Our approach has been an empirically and theoretically informed analysis of data from an ongoing study of service innovation and the impact of research in NAV.

The data from NAV supports the general claim in the traditional innovation literature that the relationship between research and innovation is neither 
linear nor instrumental. In four of our five cases of innovations, research played an initiating or inspirational role in some way, but the backstory is more complicated than a scientific breakthrough leading to an innovation. Political decisions or managerial problem-solving seem to be more important driving forces of innovation. There are many examples of independently funded research that take NAV innovations and their contexts as the empirical object of study. This seems to have limited direct influence on innovation processes, although we observe that over time, such research often becomes collaborative and harder to distinguish from the third and most important category in our material: the innovation processes that encounter problems that are resolved by procuring research. We have called this linkage researchin-innovation.

In our five cases, research contributes primarily by either providing new knowledge to help develop immature ideas and innovations-in-the-making, by studying the innovation to gain more systematic knowledge to prepare for diffusion or scaling-up, or by delivering numbers and narratives that secure funding and legitimacy.

We can visualise these research contributions as three different types of impacts (See Table 3). The first is where research helps to transform informal, practical, and decentralised information into systematic data, which often happens when innovation processes are followed over time by researchers. The second is a shift from tacit to codified knowledge, a process necessary for making the innovation into an organisational practice (for example, through training personnel and creating guidelines) and a move from a geographically or organisationally bounded experiment to a national system. The third impact we may call a shift from innovation as an organisational practice to innovation as a political currency. This is when researchers provide the arguments needed for new political decisions and more top-down funding required for the diffusion and scaling up processes of the innovation in question. The high importance placed on research for creating political legitimacy and for scaling up is perhaps the most surprising finding of our small-scale exploratory study, as these points are only discussed to a limited extent in traditional impact and public sector innovation literature. 
Table 3. Stylised summary of role of research in phases of innovation processes

\begin{tabular}{|l|l|l|l|}
\hline Innovation phase & $\begin{array}{c}\text { Function of } \\
\text { research for } \\
\text { innovation }\end{array}$ & \multicolumn{1}{|c|}{$\begin{array}{c}\text { Type of } \\
\text { research }\end{array}$} & \multicolumn{1}{|c|}{$\begin{array}{l}\text { Impact of } \\
\text { research }\end{array}$} \\
\hline Idea/invention & $\begin{array}{l}\text { Inspiration for } \\
\text { idea/framing and } \\
\text { conceptualisation of } \\
\text { possible solutions; } \\
\text { baseline for later } \\
\text { evaluations }\end{array}$ & $\begin{array}{l}\text { More or less } \\
\text { systematic review } \\
\text { of existing } \\
\text { research; } \\
\text { understanding } \\
\text { specific contexts }\end{array}$ & $\begin{array}{l}\text { Formalisation and } \\
\text { systematisation } \\
\text { (creating ties } \\
\text { between local } \\
\text { knowledge and } \\
\text { research } \\
\text { knowledge) }\end{array}$ \\
\hline Development & $\begin{array}{l}\text { Supporting } \\
\text { development and } \\
\text { implementation }\end{array}$ & $\begin{array}{l}\text { Research-based } \\
\text { evaluations } \\
\text { supporting } \\
\text { development, } \\
\text { action research, } \\
\text { monitoring, and } \\
\text { preparation for } \\
\text { RCTs }\end{array}$ & $\begin{array}{l}\text { Codification } \\
\text { (transforming } \\
\text { knowledge into } \\
\text { manuals, } \\
\text { checklists, } \\
\text { training, etc.) }\end{array}$ \\
& $\begin{array}{l}\text { Randomised } \\
\text { controlled trials; } \\
\text { effect evaluations }\end{array}$ & $\begin{array}{l}\text { Legitimisation } \\
\text { (turning } \\
\text { knowledge into } \\
\text { political currency) }\end{array}$ \\
\hline $\begin{array}{l}\text { Implementation/ } \\
\text { dissemination }\end{array}$ & $\begin{array}{l}\text { Dissemination or } \\
\text { scaling up to wider } \\
\text { organisation; } \\
\text { supporting } \\
\text { increases in public } \\
\text { funding }\end{array}$ & \multicolumn{2}{|l}{} \\
\hline
\end{tabular}

If we look at these impacts considering the three relationships between research and innovation discussed in the theory and analysis sections, we observe that all of them are primarily tied to what we have called research-ininnovation. Co-evolving research and innovation activities provide systematisation of data, codification, and politically usable evidence. Research-on-innovation might also ideally provide systematisation and codification, but this was not mentioned by the interviewees, perhaps because this research was seen as more remote from daily and strategic decisions.

Some other nuances in the data should be brought up. For example, we observed that temporality is complex: research and innovation are linked together in varying and flexible sequences of activities, and it is sometimes difficult to say whether one activity drives or initiates the other. It is not clear whether the research-innovation relationship follows a specific cycle or goes through somewhat predictable stages. One possible pattern is that a template for an innovation emerges from new political decisions and a lack of relevant knowledge, and that research comes into the process earlier when the starting point is a top-down decision. However, there are exceptions even in our small data set. 
We also see that working with innovations to some extent can have an impact on research -an issue for further studies_and that NAV has put much effort into funding ambitious projects and research units in exchange for bringing them closer to the welfare and labour context. Although we find relatively few signs of short-termism or problematic dependencies in commissioned research, the line between commissioned R\&D and independently funded research through research councils and other third-party actors may have become more blurred. In our terminology, this signals a convergence between the research in and research on innovation categories. We have argued that research may have an impact through formalisation, codification, and legitimation of innovation processes. This importance for innovation may rest on the perceived independence and trustworthiness of the research, which can pose challenges in strongly collaborative settings. This is an issue for later studies.

This paper contributes to the public innovation literature by adding insights into how the research system may be relevant for innovation processes (cf. Sørensen \& Torfing, 2011; Torfing et al., 2016) in other ways than as a source of inventions and ideas to be implemented (e.g., Heaton et al., 2016; Parkes et al., 2014; Harrison \& Graham, 2012). In the context of modern governments emphasising research-based knowledge and innovation in the public sector, a nuanced conceptualisation of such relationships is particularly valuable. 


\section{References}

Bakkeli, V., Frøyland, K., \& Spjelkavik, Ø. (2020). Supported employment-tjenester. AFI rapport 2020:04 Oslo.

Balconi, M., Brusoni, S., \& Orsenigo, L. (2010). In defence of the linear model: An essay. Research Policy, 39(1), 1-13. https://doi.org/10.1016/j.respol.2009.09.013

Bason, C. (2010). Leading Public Sector Innovation. Co-creating for a Better Society. The Policy Press. https://doi.org/10.2307/j.ctt9qgnsd

Bazeley, P. (2013). Qualitative data analysis: Practical strategies. Sage.

Berman, E. P. (2012). Creating the market university: How academic science became an economic engine. Princeton University Press. https://doi.org/10.23943/princeton/9780691147086.001.0001

Bugge, M., \& Bloch, C. (2016). Between bricolage and breakthroughs-framing the many faces of public sector innovation. Public Money \& Management, 36(4), 281-288. https://doi.org/10.1080/09540962.2016.1162599

Cohen, W. M., \& Levinthal, D. A. (1989). Innovation and learning: The two faces of R\&D. The Economic Journal, 99(397), 569-596. https://doi.org/10.2307/2233763

Drake, R. E., Becker, D. R., Clark, R. E., \& Mueser, K. T. (1999). Research on the individual placement and support model of supported employment. Psychiatric Quarterly, 70, 289-301. https://doi.org/10.1023/A:1022086131916

Eisenhardt, K. (1989). Building theories from case study research. The Academy of Management Review, 14(4), 532-550. DOI: 10.5465/amr.1989.4308385

EU. (2014). European public sector innovation scoreboard 2013: A pilot exercise. Directorate-General for Enterprise and Industry.

Fagerberg, J. (2005). Innovation: A guide to the literature. In J. Fagerberg, D. C. Mowery, \& R. R. Nelson (Eds.), The Oxford Handbook of Innovation (pp. 126). Oxford University Press.

https://doi.org/10.1093/oxfordhb/9780199286805.001.0001

Fuglsang, L., \& Rønning, R. (2014). Framing innovation in public service sectors. A contextual approach. In B. Enquist, L. Fuglsang, \& R. Rnning (Eds.), Framing innovation in public service sectors (Vol. 30, Routledge studies in innovation, organisation and technology, pp. 1-11.) Routledge.

https://doi.org/10.4324/9781315885612

Garud, R., Tuertscher, P. \& van de Ven, A. (2013). Perspectives on innovation processes. The Academy of Management Annals, 7(1), 773-817. https://doi.org/10.5465/19416520.2013.791066

Greenhalgh, T., \& Russell, J. (2009). Evidence-based policymaking: A critique. Perspectives in biology and medicine, 52(2), 304-318. https://doi.org/10.1353/pbm.0.0085

Gulbrandsen, M. \& Nerdrum, L. (2009). Public sector research and industrial innovation in Norway: a historical perspective. In Fagerberg, J., Mowery, D. \& 
Verspagen, B (Eds.), Innovation, Path-Dependency and Policy - The

Norwegian Case. Oxford University Press, pp. 61-88.

https://doi.org/10.1093/acprof:oso/9780199551552.003.0003

Harrison, M. B., \& Graham, I. D. (2012). Roadmap for a participatory research-practice partnership to implement evidence. Worldviews on Evidence-Based Nursing, 9(4), 210-220. https://doi.org/10.1111/j.1741-6787.2012.00256.x

Hartley, J. (2005). Innovation in governance and public services: Past and present. Public Money and Management, 25(1), 27-34. doi:10.1111/j.14679302.2005.00447.

Heaton, J., Day, J., \& Britten, N. (2016). Collaborative research and the co-production of knowledge for practice: An illustrative case study. Implementation Science, 11(1), 1-10. https://doi.org/10.1186/s13012-016-0383-9

Howlett, M. (2009). Policy analytical capacity and evidence-based policy-making: Lessons from Canada. Canadian Public Administration 52(2): 153-175. https://doi.org/10.1111/j.1754-7121.2009.00070_1.x

Høiland, G.C.L. (2018). Frontline policy implementation in public organizations. A sociological analysis of the 'how and why' of implementation gaps. PhD Thesis, University of Stavanger.

Kline, S. J., \& Rosenberg, N. (1986). An Overview of Innovation. In R. Landau \& N. Rosenberg (Eds.), The positive sum strategy: Harnessing technology for economic growth (pp. 275-305). The National Academies Press.

Malmberg-Heimonen, I, Natland, S, Tøge, A. G., Hansen, H., \& Innvær, S. (2014). Helhetlig oppfølging av deltakere i Kvalifiseringsprogrammet. Evaluering av «Helhetlig, prinsippstyrt, metodisk tilnærming» (HPMT). En klyngerandomisert studie. Sluttrapport til Arbeids- og velferdsdirektoratet. HIOA.

Malmberg-Heimonen, I., Tøge, A .G., Rugkåsa, M., Fossestøl, K., Liodden, T., Bergheim, B., Gyüre, K., \& Buzungu, H. F. (2019). Helhetlig oppfølging av lavinntektsfamilier Sluttrapport. Oslomet Skriftserie 2019:10. Oslo

Mazzucato, M. (2018). Mission-oriented innovation policies: Challenges and opportunities. Industry \& Corporate Change, 27(5), 803-815. https://doi.org/10.1093/icc/dty034

Miller, W. R., Rollnick, S. (2009). Ten things that motivational interviewing is not. Behavioural Cognitive Psychotherapy, 37(2), 129-40. https://doi.org/10.1017/S1352465809005128

Mowery, D., Nelson, R. R., Sampat, B. N., \& Ziedonis, A. A. (2004). Ivory tower and industrial innovation. Stanford University Press.

National Institute of Public Health, Oslo (2017). Motivational Interviewing as a method to facilitate return to work: A systematic review. Folkehelseinstituttet Report No. 2017-05.

NOU (2012). Arbeidsrettede tiltak. Oslo: Arbeids- og sosialdepartementet, NOU 2012:6 
OECD (2018). Oslo Manual 2018-Guidelines for Collecting, Reporting and Using Data on Innovation (4th ed.). OECD.

Parkes, J. H., Pyer, M., Wray, P., \& Taylor, J. (2014). Partners in projects: Preparing for public involvement in health and social care research. Health Policy, 117(3), 399-408. https://doi.org/10.1016/j.healthpol.2014.04.014

Pavitt, K. (2005). Innovation processes. In Fagerberg et al., Oxford Handbook of Innovation. Oxford University Press. DOI:

10.1093/oxfordhb/9780199286805.003.0004.

Proba Samfunnsanalyse (2016). Sluttevaluering av Hedmarksmodellen - NAVs håndtering av aktivitetskravet ved uke 8 i en sykmelding. Rapport 2016:12. Oslo.

Reme, S. E., Monstad, K., Fyhn, T., Øverland, S., Ludvigsen, K., Sveinsdottir, V., Løvvik, C., \& Lie, S. A. (2016). Effektevaluering av Individuell jobbstøtte: Sluttrapport. Uni Research Helse.

Rosenberg, N., \& Nelson, R. R. (1994). American universities and technical advance in industry. Research Policy, 23(3), 323-348. https://doi.org/10.1016/00487333(94)90042-6

Rule, P., \& John, V. M. (2015). A necessary dialogue: Theory in case study research. International Journal of Qualitative Methods, 14(4), 1-11. https://doi.org/10.1177/1609406915611575

Rycroft-Malone, J., Wilkinson, J. E., Burton, C. R., Andrews, G., Ariss, S., Baker, R., Thompson, C. (2011). Implementing health research through academic and clinical partnerships: A realistic evaluation of the Collaborations for Leadership in Applied Health Research and Care (CLAHRC). Implementation Science, 6, article 74. https://doi.org/10.1186/1748-5908-6-74

Schönfelder, W., Arntzen, C., Johansen, T., \& Munkejord, M. C. (2020). Jobbspesialister i NAV. Følgeforskning på implementering av oppfølgingstjenester i egenregi. NORCE rapport 2020:1. Stavanger.

Sveinsdottir, V., Bull, H., Evensen, S., Reme, S., Knutzen, T., \& Lystad, J. (2019). A short history of individual placement and support in Norway. Psychiatric Rehabilitation Journal 43(1), 9-17. https://doi.org/10.1037/prj0000366

Sørensen, E.\& Torfing, J. (2011). Samarbejdsdrevet innovation i den offentlige sektor. Økonomi og politik, 83(1), 22-33.

Torfing, J. (2018). Collaborative innovation in the public sector: The argument. Public Management Review, 21(1), 1-11. https://doi.org/10.1080/14719037.2018.1430248

Torfing, J., Sørensen, E., \& Røiseland, A. (2016). Transforming the public sector into an arena for co-creation: Barriers, drivers, benefits, and ways forward.

Administration \& Society, 51(5), 795-825. https://doi.org/10.1177/0095399716680057

Van de Ven, A. H., Garud, R., Venkataraman, S., \& Polley, D. (1999). The Innovation Journey. Oxford University Press. 